\title{
PHARMACOKINETICS OF CIPROFLOXACIN IN BROILER CHICKENS AFTER SINGLE INTRAVENOUS AND INTRAINGLUVIAL ADMINISTRATION
}

\author{
Sofiya Ivanova ${ }^{1}$, Dimitrichka Dimitrova $^{2}$, Metodi Petrichev $^{1}$ \\ ${ }^{I}$ Non-infectious Diseases Unit, National Diagnostic and Research Veterinary \\ Medical Institute, Sofia, Bulgaria \\ ${ }^{2}$ Department of Internal Non-infectious Diseases, Pathology and Pharmacology, \\ Faculty of Veterinary Medicine of the University of Forestry, Sofia, Bulgaria
}

Received 9 June 2016; Received in revised form 12 December 2016; Accepted 12 January 2017

\begin{abstract}
The trial was performed on 10 clinically healthy Ross hybrid chickens, 5 from each gender, weighing 2.75-2.84 kg. The tested quinolone was applied at the same dose for both routes of application $-10 \mathrm{mg} / \mathrm{kg}$ of body weight. Ciprofloxacin hydrochloridum $5 \%$ solution for i.v. and $1 \%$ solution for intraingluvial treatment were prepared. In a crossover study design, ciprofloxacin hydrochloridum was administered as $5 \%$ solution for i.v. bolus injection to broiler chickens and after 14 days as $1 \%$ solution for intraingluvial administration into a crop to the same birds. Serum ciprofloxacin concentrations were assayed by HPLC with UV detection at a wavelength of $279 \mathrm{~nm}$. After intravenous injection the following pharmacokinetic parameters were determined: $\mathrm{t}_{1 / 2 \beta}=9.07 \mathrm{~h} ; \mathrm{t}_{1 / 2 \alpha}=0.36 \mathrm{~h} ; \mathrm{MRT}=10.20 \mathrm{~h}$ and $\mathrm{MRT}=10.75 \mathrm{~h} ; \mathrm{AUC}_{0 \rightarrow \infty}=19.560 \mu \mathrm{g} \cdot \mathrm{h} / \mathrm{mL}$ and $\mathrm{AUC}_{0 \rightarrow \infty}=19.843 \mu \mathrm{g} . \mathrm{h} / \mathrm{mL}$. After intraingluvial application parameters determined by the two pharmacokinetic models were as: $\mathrm{t}_{1 / 2 \alpha}=0.86 \mathrm{~h} ; \mathrm{t}_{1 / 2 \beta}=7,20 \mathrm{~h}$ and $\mathrm{t}_{1 / 2 \beta}=7.89 \mathrm{~h} ; \mathrm{MRT}=12.67 \mathrm{~h}$ and $\mathrm{MRT}=12.93 \mathrm{~h} ; \mathrm{AUC}_{0 \rightarrow \infty}=11.340 \mu \mathrm{g} \cdot \mathrm{h} / \mathrm{mL}$ and AUC $\mathrm{AU}_{0 \rightarrow 24 \mathrm{~h}}=$ $11.973 \mu \mathrm{g} . \mathrm{h} / \mathrm{mL} ; \mathrm{C}^{2}=2.841 \mu \mathrm{g} / \mathrm{mL}^{1 / 2 \beta}$ and $\mathrm{C}_{\max }=2.638 \mu \mathrm{g} / \mathrm{mL} ; \mathrm{T}_{\max }=0.48 \mathrm{~h}$ and $\mathrm{T}_{\mathrm{max}}=0.39 \mathrm{~h} ; \mathrm{t}_{12 \mathrm{abs}}=0.146 \mathrm{~h} ; \mathrm{MAT}=2.47 \overrightarrow{\mathrm{h}}^{24 \mathrm{~h}}$ $\mathrm{MAT}=2.18 \mathrm{~h} ; \mathrm{F}=57.91 \%$ and $\mathrm{F}=63.89 \%$. These results suggested that a dose of $10 \mathrm{mg} / \mathrm{kg}$ of body weight provides maximum plasma concentration ater intraingluvial administration and is effective in the control of many infectious diseases of poultry.
\end{abstract}

Key words: ciprofloxacin, pharmacokinetics, chickens

\section{INTRODUCTION}

Ciprofloxacin is a fluorinated quinolone with a broad antimicrobial spectrum and high bactericidal activity. It is highly effective against a variety of bacteria - Gram-negative, including Pseudomonas and Enterobacteriaceae, as well as some Grampositive organisms and many anaerobes and facultative anaerobes. In-vitro tests of the effects of different quinolones against some bacterial pathogens in veterinary practice demonstrated

Corresponding author: Prof. Dimitrichka J. Dimitrova, $\mathrm{PhD}$ E-mail address: dj.dimitrova.56@gmail.com

Present address: Department of Internal Non-infectious Diseases, Pathology and Pharmacology, Faculty of Veterinary Medicine of the

University of Forestry, Sofia, Bulgaria

Phone: +359028192951

Copyright: (C) 2017 Ivanova S. This is an open-access article published under the terms of the Creative Commons Attribution License which permits unrestricted use, distribution, and reproduction in any medium, provided the original author and source are credited.

Competing Interests: The authors have declared that no competing interests exist.

Available Online First: 1 February 2017

Published on: 15 March 2017

http://dx.doi.org/10.1515/macvetrev-2017-0013 that it is most efficient against Gram-negative microorganisms and mycoplasmae $(1,2)$. The pyperazine ring to position 7 of the ciprofloxacin molecule is responsible for its activity against Pseudomonas, while the fluorine atom at position 6 confers activity against some Gram-positive bacteria $(3,4)$.

The bactericide activity of ciprofloxacin, similarly to other fluoroquinolones, is due to the effect on bacterial DNA gyrase (5). The drug suppresses DNA gyrase through interaction with microbial DNA (2).

Ciprofloxacin is well tolerated by animals after parenteral application (6-13). In the organism, it is metabolised in the liver. In humans, there are fiur ciprofloxacin metabolites (sulfociprofloxacin, oxociprofloxacin, desethylenciprofloxacin and formyl-ciprofloxacin), which are excreted with the bile. In animals, it is converted only to two metabolites - desethyl-eneciprofloxacin and oxociprofloxacin, detected in the urine of calves and monkeys $(6,14)$. 
The possible use of ciprofloxacin for treatment of infections, provoked by Mycoplasma and secondary infections (respiratory colibacillosis and pasteurellosis) in birds and pigs requires detailed information about the pharmacokinetic behaviour - distribution, metabolism, elimination and bioavailability of ciprofloxacin in food-producing animal species. Therefore, the purpose of the present experiment was to follow up the pharmacokinetics of this fluoroquinolone in broiler chickens after intravenous and intraingluvial application.

\section{MATERIAL AND METHODS}

\section{Animals and housing}

The present pharmacokinetic experiment was conducted with 10 sexually mature Ross broiler chickens from both sexes, 60 days of age, weighing 2.75 to $2.840 \mathrm{~kg}$. They were reared in compliance with the standards for the species and fed a compound feed for stock layers. The ambient temperature in the premise was $22-23^{\circ} \mathrm{C}$, with continuous ventilation and mixed lighting regimen: 12-hour light period between 8.00 AM and 8.00 PM. The birds were floor reared, and food and water were provided ad libitum. Before the beginning of the pharmacokinetic trial, the birds were neither vaccinated nor treated with other drugs.

\section{Drugs}

In this study, the substance ciprofloxacin hydrochloridum was used (Actavis Ltd, Sofia, Bulgaria), dissolved ex tempore in sterile distilled water to obtain $5 \%$ solution for intravenous and $1 \%$ solution for oral (intraingluvial) application.

\section{Experimental design}

The tested fluoroquinolone was applied once, intravenously or intraingluvially at a dose of $10 \mathrm{mg} /$ $\mathrm{kg}$ of body weight after preliminary dissolution in sterile distilled water. Intravenous solutions were warmed to $37^{\circ} \mathrm{C}$, whereas the solution for oral use was at room temperature.

For intravenous application, solutions were injected in the wing vein (v. brachialis) of the right wing of chickens, and those for oral application were introduced in the crop by means of an elastic silicone probe and a syringe. The intraingluvial application was performed after a 16-hour fasting period (from 4.00 PM the day before to 8.00 AM on the test day). Food deprivation continued for another 6 hours after the crop administration of the drug. Water was withheld for $4 \mathrm{~h}$ ( $1 \mathrm{~h}$ before ciprofloxacin application and $3 \mathrm{~h}$ after that). A 2-week wash-out period was allowed between the two routes of application of the quinolone.

Care and handling of animals were performed in accordance with the provisions for welfare of Regulation (EC) No 882/2004 of the European Parliament and of the Council of 29 April 2004 adopted by the Government of the Republic of Bulgaria with Ordinance No 20 from 01.11.2012.

\section{Blood sampling}

Blood samples of $1 \mathrm{~mL}$ were collected from the left wing's $v$. brachialis before drug application and at post treatment hours $0.085,0.17,0.33,0.50,1,2$, $3,4,5,9,12$ and 24 . The serum was separated by centrifugation at $1500 \times \mathrm{g}$ for $10 \mathrm{~min}$. Blood serum samples was stored frozen at $-25^{\circ} \mathrm{C}$ over 3 days until analysis.

\section{Analysis of samples}

For assays, ciprofloxacin hydrochloridum substance purchased from Actavis Ltd - Sofia was used, as well as acetonitrile HPLC grade (Merck); triethylamine (TEA; Merck); tetrabutyl ammonium hydrochloride 40\% (TBA, Merck); phosphoric acid $85 \%$ (Merck) and perchloric acid for analysis 70\% (Merck). The water used in the analyses was treated through a Millipore purifying system.

\section{Chromatography system}

Serum ciprofloxacin concentrations were assayed by HPLC with UV detection according to the slightly modified method of Imre et al. (15). The difference consisted in substituting blood serum for plasma. The chromatography was run on HPLC system Waters equipped with quaternary pump, HPLC with UV detector, protected and analytical columns Lichrospher (Beckman).

The mobile phase consisted of acetonitrile and water (1:1), supplemented with $3 \%$ potassium phosphate buffer, 2\% TEA and 2\% TBA. Mobile phase pumping rate was $1.2 \mathrm{ml} / \mathrm{min}$. Chromatograms were integrated with a computer program.

The reference standard of ciprofloxacin was used to prepare a stock solution, which was used to fortify serum from untreated chikens (control serum).

The calibration curve for ciprofloxacin consisted of 7 standard solutions that ranged from 0.05 to $10 \mu \mathrm{g} / \mathrm{mL}$ and included a blank $(0 \mu \mathrm{g} / \mathrm{mL})$ sample. The calibration curve was accepted if the linear coefficient of determination $(R 2)$ was $\geq 0.99$ and if 
the calibration curve concentrations could be backcalculated to within $<15 \%$ of the true concentration of the standard. All serum, calibration, qualitycontrol, and blank serum samples were prepared in an identical manner.

\section{Preparation of samples}

Blood proteins were precipitated by consecutive addition of two acids $-85 \%$ phosphoric acid and $70 \%$ perchloric acid to $100 \mu \mathrm{L}$ serum, homogenisation by a vortex mixer and centrifugation at $1500 \times \mathrm{g}$ for $10 \mathrm{~min}$. One hundred $\mu \mathrm{l}$ aliquots of the supernatant were injected in the HPLC system.

\section{Assay validation}

Serum ciprofloxacin concentrations were calculated from standard curves from spiked matrix standards. The method of external calibration curves was used for assay validation.

The limit of quantitation (LOQ) for ciprofloxacin was $0.035 \mu \mathrm{g} / \mathrm{mL}$, and the limit of detection (LOD) $0.005 \mu \mathrm{g} / \mathrm{mL}$. The precipitation of serum proteins did not alter the recovery of ciprofloxacin. Intra-day and inter-day coefficients of variation of the method ranged between $5.9-9.19 \%$, and $6.7-12.1 \%$, respectively.

\section{Pharmacokinetic analysis}

The TopFit, v. 2.0. software was used for pharmacokinetic investigation of serum concentration time curves after single intravenous or intraingluvial application (16). For description of drug behaviour, two pharmacokinetic models were used-compartmental and non-compartmental analysis (17). The pharmacokinetic modelling was done according to Akaike's criterion (18). Pharmacokinetic parameters were presented as means (Means) \pm standard error (SE). The absolute bioavailability (F) after intramuscular injection of fluoroquinolone solution was calculated as per the equation:

$\mathrm{F}(\%)=\left[\left(\mathrm{AUC}_{0 \rightarrow \infty \text {.o. } \mathrm{X}} \mathrm{D}_{i . v}\right) /\left(\mathrm{AUC}_{0 \rightarrow \infty \text { i.v. X }} \mathrm{D}_{\text {p.o. }}.\right)\right] \mathrm{X} 100$.

Mean absorption times (MAT) were calculated by the formula:

$$
\mathrm{MAT}=\mathrm{MRT}_{p . o .}-\mathrm{MRT}_{i . v .}(16) .
$$

\section{RESULTS}

The mean serum ciprofloxacin concentrations assayed after single intravenous or intraingluvial application to broiler chickens are presented on Fig. 1. After the i.v. injection of the aqueous solution of the drug, serum levels remained higher than $0.24 \mu \mathrm{g} / \mathrm{mL}$ up to the $24^{\text {th }} \mathrm{h}$ (Fig. 1).

Table 1. Selected pharmacokinetic parameters of ciprofloxacin after single intravenous application to broiler chickens at a dose of $10 \mathrm{mg} / \mathrm{kg}$ of body weight (mean $\pm \mathrm{SE}$ )

\begin{tabular}{|c|c|c|c|c|c|c|c|}
\hline \multirow[t]{2}{*}{ Parameter } & \multirow[t]{2}{*}{ Units } & \multicolumn{2}{|c|}{$\begin{array}{c}\text { Compartmental } \\
\text { analysis }\end{array}$} & \multirow[t]{2}{*}{ Parameter } & \multirow[t]{2}{*}{ Units } & \multicolumn{2}{|c|}{$\begin{array}{c}\text { Non-compartmenta } \\
\text { analysis }\end{array}$} \\
\hline & & Mean & SE & & & Mean & SE \\
\hline $\mathbf{t}_{1 / 2 \alpha}$ & $\mathrm{h}$ & 0.36 & 0.01 & $t_{1 / 2 \beta}$ & $\mathrm{h}$ & 9.82 & 0.97 \\
\hline$t_{1 / 2 \beta}$ & $\mathrm{h}$ & 9.07 & 1.87 & MRT & $\mathrm{h}$ & 10.75 & 0.76 \\
\hline MRT & $\mathrm{h}$ & 10.20 & 1.28 & $\mathrm{AUC}_{0 \rightarrow 24 \mathrm{~h}}$ & $\mu \mathrm{g} . \mathrm{h} / \mathrm{mL}$ & 19.027 & 1.26 \\
\hline $\mathbf{k}_{12}$ & $h^{-1}$ & 2.741 & 1.14 & $\mathrm{AUC}_{0 \rightarrow \infty}$ & $\mu \mathrm{g} . \mathrm{h} / \mathrm{mL}$ & 19.843 & 0.42 \\
\hline $\mathbf{k}_{21}$ & $\mathrm{~h}^{-1}$ & 0.348 & 0.52 & $\mathrm{Cl}_{\mathrm{B}}$ & $\mathrm{mL} / \mathrm{min} / \mathrm{kg}$ & 0.31 & 0.01 \\
\hline $\mathbf{k}_{\mathrm{el}}$ & $\mathrm{h}^{-1}$ & 1.408 & 0.36 & $\mathrm{~V}_{\mathrm{d}}$ & $\mathrm{L} / \mathrm{kg}$ & 4.86 & 0.34 \\
\hline $\mathrm{Cl}_{\mathrm{B}}$ & $\mathrm{mL} / \mathrm{min} / \mathrm{kg}$ & 0.36 & 0.12 & $r^{2}$ & - & 0.995 & 0.09 \\
\hline $\mathbf{A} \mathbf{U} \mathbf{C}_{0 \rightarrow \infty}$ & $\mu \mathrm{g} . \mathrm{h} / \mathrm{mL}$ & 19.563 & 1.54 & & & & \\
\hline $\mathbf{V} \mathbf{d}_{\text {(area) }}$ & $\mathrm{L} / \mathrm{kg}$ & 5.43 & 1.46 & & & & \\
\hline $\mathbf{V}_{\mathrm{ss}}$ & $\mathrm{L} / \mathrm{kg}$ & 4.83 & 0.78 & & & & \\
\hline
\end{tabular}

$\mathrm{t}_{1 / 2 \alpha}$ - distribution half-life; $\mathrm{t}_{1 / 2 \beta}$ - elimination half-life; MRT - mean residence time; $\mathrm{k}_{12}-$ transfer rate constant from the central to the peripheral compartment; $\mathrm{k}_{21}$ - transfer rate constant from the peripheral to the central compartment; $\mathrm{k}_{\mathrm{el}}$ - elimination rate constant; $\mathrm{V}_{\mathrm{ss}}$ - steady-state volume of distribution; $\mathrm{Vc}$ - volume of distribution in the central compartment; Vd - volume of distribution; $\mathrm{CL}_{\mathrm{B}}$

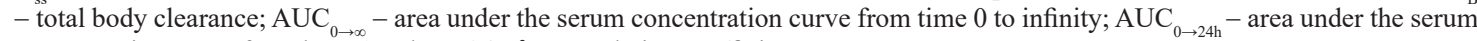
concentration curve from hour 0 to hour $24 ; \mathrm{r}^{2}-$ correlation coefficient 


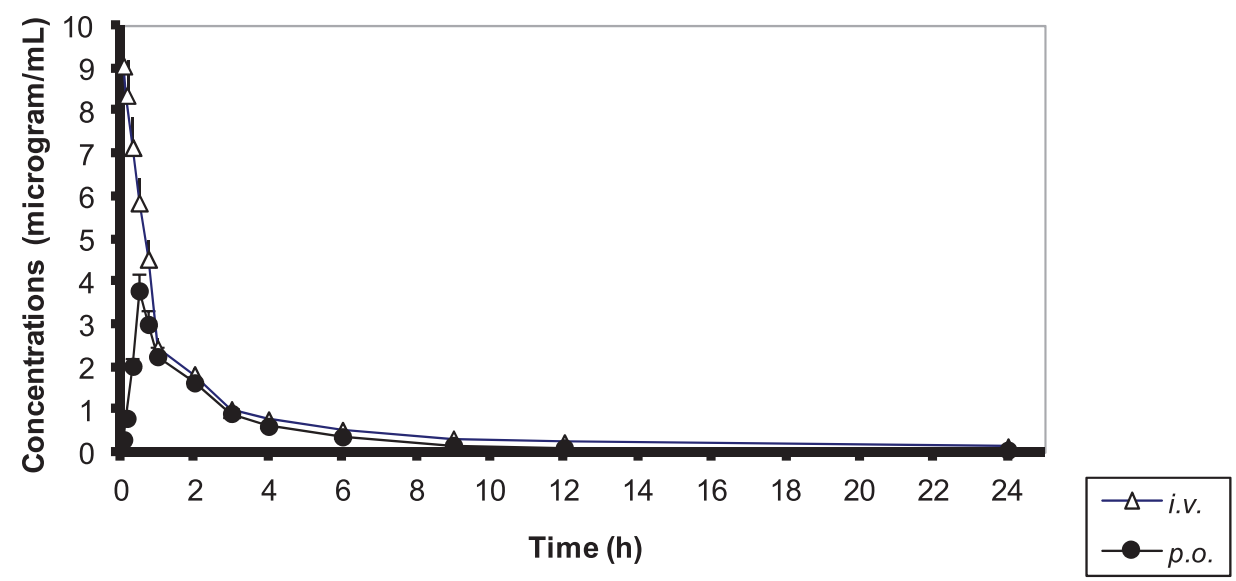

Figure 1. Serum ciprofloxacin concentrations after single intravenous (i.v.) or intraingluvial (p.o.) application to broiler chickens

After the intravenous application, ciprofloxacin concentrations in 8 treated broilers exhibited a biexponential relationship with time, with an initial distribution phase $(\alpha)$ (approximately up to $0.75 \mathrm{~h}$ ), followed by a slower elimination phase $(\beta)$ and a long elimination half-life (Table 1). For the other two birds (both of them male), drug concentrations were monoexponential with respect to time.

Serum concentrations after the intraingluvial application of the tested fluoroquinolone were detectable as early as the first blood sampling - by hour 0.08 and were over the limit of quantification
(LOQ) until the $24^{\text {th }}$ hour (Fig. 1). The parenteral application of $5 \%$ solution of the drug resulted in rapid attainment of maximum serum concentrations $\left(\mathrm{C}_{\max }\right)$ - after about 20-25 min. Intraingluvially treated birds exhibited biexponential reduction of fluoroquinolone levels in all birds, rapid distribution ( $\alpha$ phase) and prolonged elimination ( $\beta$ phase).

The rate of absorption of ciprofloxacin in intraingluvially treated birds is presented in Table 2 and were characterised by pharmacokinetic parameters $\mathrm{t}_{1 / 2 \mathrm{abs}}$ and MAT.

Table 2. Selected pharmacokinetic parameters of ciprofloxacin after single intraingluvial application to broiler chickens at a dose of $10 \mathrm{mg} / \mathrm{kg}$ body weight (mean $\pm \mathrm{SE}$ )

\begin{tabular}{|c|c|c|c|c|c|c|c|}
\hline \multirow[t]{2}{*}{ Parameter } & \multirow[t]{2}{*}{ Units } & \multicolumn{2}{|c|}{$\begin{array}{c}\text { Compartmental } \\
\text { analysis }\end{array}$} & \multirow[t]{2}{*}{ Parameter } & \multirow[t]{2}{*}{ Units } & \multicolumn{2}{|c|}{$\begin{array}{c}\text { Non-compartmental } \\
\text { analysis }\end{array}$} \\
\hline & & Mean & SEM & & & Mean & SEM \\
\hline$t_{1 / 2 \alpha}$ & $\mathrm{h}$ & 0.86 & 0.09 & $t_{1 / 2 \beta}$ & $\mathrm{h}$ & 7.89 & 1.14 \\
\hline$t_{1 / 2 \beta}$ & $\mathrm{h}$ & 7.20 & 0.84 & MRT & $\mathrm{h}$ & 12.93 & 0.87 \\
\hline MRT & $\mathrm{h}$ & 12.67 & 0.76 & $\mathrm{AUC}_{0 \rightarrow 24 \mathrm{~h}}$ & $\mu \mathrm{g} . \mathrm{h} / \mathrm{mL}$ & 11.97 & 0.62 \\
\hline$t_{1 / 2 a b s .}$ & $\mathrm{h}$ & 0.15 & 0.01 & $\mathrm{AUC}_{0 \rightarrow \infty}$ & $\mu \mathrm{g} \cdot \mathrm{h} / \mathrm{mL}$ & 12.98 & 1.10 \\
\hline $\mathbf{A} \mathbf{U} \mathbf{C}_{0 \rightarrow \infty}$ & $\mu \mathrm{g} \cdot \mathrm{h} / \mathrm{mL}$ & 11.34 & 1.11 & $\mathrm{C}_{\max }$ & $\mu \mathrm{g} / \mathrm{mL}$ & 2.638 & 0.46 \\
\hline $\mathrm{C}_{\max }$ & $\mu \mathrm{g} / \mathrm{mL}$ & 2.841 & 0.28 & $\mathrm{~T}_{\max }$ & $\mathrm{h}$ & 0.39 & 0.17 \\
\hline $\mathbf{T}_{\max }$ & $\mathrm{h}$ & 0.48 & 0.09 & MAT & $\mathrm{h}$ & 2.18 & 0.29 \\
\hline MAT & $\mathrm{h}$ & 2.47 & 0.34 & $\mathrm{~F}$ & $\%$ & 63.89 & 0.34 \\
\hline $\mathbf{F}$ & $\%$ & 57.91 & 0.11 & $r^{2}$ & - & 0.987 & 0.34 \\
\hline
\end{tabular}

$\mathrm{t}_{1 / 2 \alpha}$ - distribution half-life; $\mathrm{t}_{1 / 2 \beta}$ - elimination half-life; $\mathrm{t}_{1 / 2 \mathrm{abs}}$ - absorption half-life; MRT - mean residence time; MAT - mean absorption time; $\mathrm{AUC}_{0 \rightarrow 24 \mathrm{~h}}$ - area under the plasma concentration curve from hour 0 to hour $24 ; \mathrm{C}_{\max }-$ maximum serum concentrations after intraingluvial application; $\mathrm{T}_{\max }$ - time to reach maximum serum concentration; $\mathrm{F}$ - absolute bioavailability of the drug; $\mathrm{r}^{2}-$ correlation coefficient 


\section{DISCUSSION}

In this study, serum ciprofloxacin concentration and the pharmacokinetic behaviour of the tested fluoroquinolone were established in adult clinically healthy broiler chickens. It should be emphasized that after intravenous application to broiler-type birds, the drug exhibited an initial rapid distribution phase (up to $0.36 \mathrm{~h}$, followed by a continuous elimination phase. This finding is in agreement with results reported by other researchers on the administration of this antibiotic in different broiler chicken strains at various dose rates $(9,11,12,19)$. Similarly to others' reports $(9,12)$ in 8 out of the ten i.v. injected chickens, serum curves were well fitted to a two-compartmental open pharmacokinetic model. In injected broiler chickens, ciprofloxacin was characterised with a long elimination period, as evidenced by elimination half-life of the drug $\left(\mathrm{t}_{1 / 2 \beta}\right)$ and mean residence time (MRT) values calculated by both used pharmacokinetic models (compartmental and non-compartmental analysis) which were higher than data obtained in broiler chickens by García Ovando et al. $\left(\mathrm{t}_{1 / 2 \beta}=3.11 \pm 0.25 \mathrm{~h}\right)$, Raina et al. $\left(\mathrm{t}_{1 / 2 \beta}=5.79 \pm 1.14 \mathrm{~h}\right)$, Anadón et al. $\left(\mathrm{t}_{1 / 2 \beta}=8.84 \pm 2.13 \mathrm{~h}\right)$, but similar to those of Atta and Scharif $\left(\mathrm{t}_{1 / 2 \beta}=9.01 \pm 0.79 \mathrm{~h}\right)(9,11,12,19)$. The longer elimination half-life $\left(t_{1 / 2 \beta}\right)$ in i.v. treated broiler chickens in our experiment was probably due to the different used ciprofloxacin dosage. It is obvious that if concentration is higher, then the elimination process is longer.

The area under the concentration time curve $\left(\mathrm{AUC}_{0 \rightarrow \infty}\right)$ after i.v. administration of ciprofloxacin to broiler chickens (Table 1) was higher than those reported by Raina et al. $\left(\mathrm{AUC}_{0 \rightarrow \infty}=4.54 \pm 0.59 \mu \mathrm{g} . \mathrm{h} / \mathrm{mL}\right.$ ), García Ovando et al. $\left(\mathrm{AUC}_{0 \rightarrow \infty}=5.67 \pm 0.52 \mu \mathrm{g} . \mathrm{h} / \mathrm{ml}\right)$, Anadón et al. $\left(\mathrm{AUC}_{0 \rightarrow \infty}=17.71 \pm 4.75 \mu \mathrm{g} . \mathrm{h} / \mathrm{mL}\right.$ ) and lower than that observed by Atta and Scharif in chickens $\left(\mathrm{AUC}_{0 \rightarrow \infty}=78.04 \pm 9.45 \mu \mathrm{g} . \mathrm{h} / \mathrm{mL}\right)(9,11$, $12,19)$.

It was demonstrated that after intraingluvial application, ciprofloxacin was rapidly absorbed from the digestive tract of chickens, as indicated by the values of $\mathrm{t}_{1 / 2 \text { abs., }} \mathrm{T}_{\max }$ and $\mathrm{C}_{\max }$ (Table 2). Our values are comparable to those published by other research teams $(9,12,20)$.

In this pharmacokinetic study, the elimination half-life $\left(\mathrm{t}_{1 / 2 \beta}\right)$ and the mean residence time (MRT) (Table 2) following intraingluvial application of the fluoroquinolone, determined by both pharmacokinetic models - compartmental and non-compartmental analysis - were longer than those reported by Raina et al. $\left(\mathrm{t}_{1 / 2 \beta}=4.37 \pm 0.36 \mathrm{~h}\right.$ and MRT $=6.17 \pm 0.49 \mathrm{~h}$ ) (12), and similar or close to data of Anadón et al. $\left(\mathrm{t}_{1 / 2 \beta}=11.89 \pm 1.95 \mathrm{~h}\right.$; MRT = $13.32 \pm 2.65$ h) (20). Hypothetically, the differences vs Raina et al. could be attributed to the different applied doses and experimental design, as well as to the different broiler chicken strains used (20).

The absolute bioavailability (F) of the tested fluoroquinolone after oral administration into the crop, was lower than that reported by Anadón et al. $(\mathrm{F}=70.09 \pm 9.8 \%)$ in broiler chickens treated via the same route at $8 \mathrm{mg} / \mathrm{kg}(12)$.

When evaluating data after the single crop application of ciprofloxacin to 2-month-old broiler chickens, the presence of individual antimicrobial drug concentrations $>0.1 \mu \mathrm{g} / \mathrm{mL}$ between post treatment hours 0.08 and 12 deserves to be pointed out, as it contributes to a 12-hour antimicrobial activity higher than MICs of a number of clinically important microbial pathogens for this poultry species.

\section{ETHICAL APPROVAL}

All procedures performed in studies involving animals were in accordance with the ethical standards of the institution at which the study was conducted. The experimental procedure was approved by the Ethical Committee at the National Diagnostic and Research Veterinary Medical Institute (Protocol No 61$\mathrm{A} / 19.03 .2012$ ).

\section{CONFLICT OF INTEREST STATEMENT}

The authors declared that they have no potential conflict of interest with respect to the authorship and/or publication of this article.

\section{ACKNOWLEDGEMENT}

We would like to thank Mrs Dimitrinka Tsoneva for the HPLC laboratoty analysis.

\section{REFERENCES}

1. Hannan, P.C.T., O'Hanlon, P.J., Rogers, N.H. (1989). In vitro evaluation of various quinolone antibacterial agents against veterinary mycoplasmas and porcine respiratory bacterial pathogens. Research in Veterinary Science 46, 202-211. PMid:2704885 
2. Prescott, J., Yielding, K.H. (1990). In vitro susceptibility of selected veterinary bacterial pathogens to ciprofloxacin, enrofloxacin and norfloxacin. Canadian Journal of Veterinary Research 54, 195-197.

3. Neer, T.M. (1988). Clinical pharmacologic features of fluoroquinolone antimicrobial drugs. Journal of American Veterinary Medical Association 193, 577580 .

4. Vancustem, P.M., Babish, J.G., Schwark, W.S. (1990). The fluoroquinolone antimicrobials, clinical use in domestic animals and toxicity. Cornell Veterinarian 80, 173-186.

5. Gellert M. (1981). DNA topoisomerases. Annual Reviews of Biochemistry 50, 879-910. https://doi.org/10.1146/annurev.bi.50.070181.004311 PMid:6267993

6. Nouws, J.F.M., Mevius, D.J., Vree, T.B., Baars, A.M., Laurensen, J. (1988). Pharmacokinetics, renal clearance and metabolism of ciprofloxacin following intravenous and oral administration to calves and pigs. Veterinary Quarterly 10, 156-163. https://doi.org/10.1080/01652176.1988.9694165 PMid:3176294

7. Walker, R.D., Stein, G.E., Hauptman, J.G., MacDonald, K.H., Budsberg, S.C., Rosser, E.J.Jr. (1990). Serum and tissue cage fluid concentrations of ciprofloxacin after oral administration of the drug to healthy dogs. American Journal of Veterinary Research 51, 896-900.

8. Parikh, V., Shivprakash, K., Patel, D., Gandhi, T.P., Patel, R.B., Santani, D.D. (1996). Effect of aspirin on single and multiple dose pharmacokinetics of ciprofloxacin in rabbits. Indian Journal of Pharmacology 28 (10): 25-28.

9. Atta, A.H., Sharif, L. (1997). Pharmacokinetics of ciprofloxacin folowing intravenous and oral administration in broiler chickens. Journal of Veterinary Pharmacology and Therapeutics 20, 326-329. https://doi.org/10.1046/j.1365-2885.1997.00065.x

10. Nouaille-Degorce, B., Veau, C., Dautrey, S., Tod, M., Laouari, D., Carbon, C., Farinotti, R. (1998). Influence of renal failure on ciprofloxacin pharmacokinetics in rats. Antimicrobial Agents and Chemotherapy 42, 289-292.

11. García Ovando, H., Gorla, N., Luders, C., Poloni, G., Errecalde, C., Prieto, G., Puelles, I. (1999). Comparative pharmacokinetics of enrofloxacin and ciprofloxacin in chickens. Journal of Veterinary Pharmacology and Therapeutics 22, 209-212. https://doi.org/10.1046/j.1365-2885.1999.00211.x
12. Anadón, A., Martínez-Larraňaga, M.R., Iturbe, J., Martínez, M.A., Díaz, M.J., Frejo, M.T., Martínez, M. (2001). Pharmacokinetics and residues of ciprofloxacin and its metabolites in broiler chickens. Research in Veterinary Science 71, 101-109. https://doi.org/10.1053/rvsc.2001.0494 PMid:11883887

13. Bashir, S. (2007). Pharmacokinetics of Ciprofloxacin in Normal and Different Metabolically Altered Conditions in Rabbits, $\mathrm{PhD}$ Thesis, University College of Pharmacy, University of the Punjab Lahore, Pakistan.

14. Siefert, H.M., Maruhn, D., Maul, W., Förster, D., Ritter, W. (1986). Pharmacokinetics of ciprofloxacin. Arzneimittelforschung Drug Research 36, 14961502.

15. Imre, S., Dogaru, M.T., Vari, C.E., Muntean, T., Kelemen, L. (2003). Validation of an HPLC method for the determination of ciprofloxacin in human plasma. Journal of Pharmaceutical and Biomedical Analysis 33, 125-130.

https://doi.org/10.1016/S0731-7085(03)00151-1

16. Heinzel, G., Wolszcak, R., Tomann, P. (1993). TopFit ${ }^{\circledR 2.0 . \quad P h a r m a c o k i n e t i c ~ a n d ~}$ pharmacodynamic data analysis for the PC. Gustav Fisher Verlag, Stuttgart, Germany.

17. Gibaldi, M., Perrier, D. (2007). Noncompartimental analysis based on the statistical moment theory. In: Gibaldi M, Perrier D, (Eds). Pharmacokinetics (pp. 409-419), 2nd ed., Revised and Expanded, Informa Healthcare Inc., New York, USA.

18. Yamaoka, K., Nakagava, T., Uno, T. (1978). Application of Akaikeds information criterion (AIC) in the evaluation of linear pharmacokinetic equations. Journal of Pharmacokinetics and Biopharmaceutics 6, 166-171. https://doi.org/10.1007/BF01117450

19. Raina, R., Prawez, S., Dimitrova, D.J., Verma, P.K., Pankaj, N.K. (2007a). Pharmacokinetics of ciprofloxacin following intravenous administration in WLH chikens (Gallus domesticus). Journal of Veterinary Pharmacology and Toxicology 6, 6-11.

20. Raina, R., Prawez, S., Pankaj, N.K., Verma, P.K. (2007b). Pharmacokinetics of ciprofloxacin after single oral administration to WLH chicken (Gallus domesticus). Tamilnadu Journal of Veterinary and Animal Sciences 3, 254-259. 